\title{
Paravertebral injections: techniques and indications
}

\author{
Jose Baeza-Noci \\ Virgen del Consuelo Hospital, Valencia, Spain.
}

\section{ABSTRACT}

\section{ठOPEN ACCESS}

\section{Citation}

Baeza-Noci J. Paravertebral injections: techniques and indications [abstract]. Proceedings of the 5Th WFOT Meeting; 2016 Nov 18-20; Mumbai, India. J Ozone Ther. 2018;2(2). doi: 10.7203/jo3t. 2.2.2018.11147

\section{Academic Editor}

Jose Baeza-Noci,

School of Medicine, Valencia University, SPAIN

\section{Editor}

World Federation of Ozone Therapy, Bolgna, ITALY

\section{Received}

December 9, 2017

\section{Accepted}

December 10, 2017

\section{Published}

March 4, 2018

\section{Intellectual Property}

Jose Baeza-Noci. This is an open access article distributed under the terms of the Creative Commons Attribution License (CC BY 4.0), which permits unrestricted use, distribution, and reproduction in any medium, provided the original author and source are credited.

\section{Author Information}

baeza@comv.es
The paravertebral injections were first referred in 1989 by Dr. Cesare Verga [1], an italian orthopedist. He used them to treat disc herniation. We call them "classical paravertebral injections". Later on, one colleague of him, Dr. Scuccimarra [2], used longer needles to inject ozone close to the foramen, under the hypothesis of improving the results, and he succeeded. They are known as "deep paravertebral injections". Other techniques have been developed in order to improve the results, reduce the risks and shorten the treatment.[3-9]

The classical paravertebral approach is done locating the upper part of the spinous process of the superior vertebrae involved in the disco-radicular conflict and injecting $2,5 \mathrm{~cm}$ to the left and right of the spinous process with a $0,8 \times 40 \mathrm{~mm}$ needle an amount of $5-10 \mathrm{~mL}$ per point depending on the size of the patient. Some authors(63) have proved that using lower ozone concentration $(10 \mu \mathrm{g} / \mathrm{mL})$ can be as useful as standard concentration (20 $\mu \mathrm{g} / \mathrm{mL}$ ). Our advice is to use a $0,4 \times 40 \mathrm{~mm}$ needle or thinner if available. Local, topic anesthesia or cryotherapy can be used to reduce the pain of the needle. Injection should be done slowly. Using local anesthesia in the muscle can reduce the effect of ozone injection. The "deep paravertebral injection" uses a similar procedure, but the distance from the middle line is narrower $(1,5 \mathrm{~cm}$ for cervical and dorsal injection and $2 \mathrm{~cm}$ for lumbar injection) and it is necessary using longer needles $(0,4$ or $0,5 \times 90 \mathrm{~mm}$ spinal needle) to be able to locate the posterior joints with the tip of the needle an inject periarticularly. The amount of ozone used is the same.

It is also possible to inject over the laminae, close to the foramen, instead of around the facet joints, but risk of accidental dura or radicular puncture is greater (although without permanent side effects); this can be done for nerve root de-inflammation. Dr Verga modified his technique for cervical and dorsal disc herniation, narrowing the distance from the spinous process to $1,5 \mathrm{~cm}$ left and right, using shorter needles $(25$ or $30 \mathrm{~mm})$ and decreasing the ozone volume per point to 3-7 mL. Dorsal approach uses the same technique as for cervical paravertebral injections.

The classical paravertebral injection produce a relaxation in the muscle spam of the lumbar spine in low back pain. The deep paravertebral injection produce an anti-inflammatory effect that can reduce inflammation on the facet joint or nerve root, depending on the point of injection. 
Based on this empirical approach, and the publications that have already used them , the indications of these injections are:

- Disc herniation [1-2]

- Spondylolysis [10]

- Spondylosis [11-14]

- Lumbar spinal stenosis $[7,15]$

- Symptomatic treatment of facet joint disease [7]

- Mechanical low back pain

These injections may have side effects due to the technique itself, not the ozone, but we have few reports on anecdotal cases, most of them without aftermath.

\section{REFERENCES}

1. Verga C. Nuovo approccio terapeutico alle ernie e protusioni discali lombari. Rivista Di Neuroradiologia 1989;2:148.

2. Scuccimarra A. The "Laminoforaminal Technique" in Oxygen-Ozone Therapy for Lumbar Disc Herniation. Riv It Ossigeno-Ozonot 2003;2(2): 193-196.

3. Juncopilla N, Franzini M. The therapy involving the infiltration of oxygenozone intradisc and interfacet. In: Sociedad Española de abordajes percutaneos vertebrales. 1er Congresso de la Sociedad Española de abordajes percutaneos vertebrales. Barcelona: Sociedad Española de abordajes percutaneos vertebrales; 1995.

4. Muto M, Andreula C, Leonardi M. Treatment of herniated lumbar disc by intradiscal and intraforaminal oxygen-ozone (O2-O3) injection. J Neuroradiol 2004;31(3):183-189.

5. Borrelli E. Mechanism of action of oxygen ozone therapy in the treatment of disc herniation and low back pain. Acta Neurochir Suppl 2011;108:123-5. doi: 10.1007/978-3-211-99370-5_19.

6. Mattozi I, Laurini G, Muzzi G, Franzini M, Bigiotti A. Intrasacral epidural injection with oxygen-ozone for the treatment of low back pain. Comparison and evaluation with other techniques and rehabilitation and return to work. European Journal of Clinical Investigation 2003;suppl. 33:45.

7. Alexandre A, Coro L, Paradiso R, Alexandre AM, Fraschini AL, Spaggiari PG. Treatment of symptomatic lumbar spinal degenerative pathologies by means of combined conservative biochemical treatments. Acta Neurochir Suppl 2011;108:127-135.

8. Dall'aglio R, Gomez-Moraleda M, Cardoso C, Alexandre A, Fraschini F. Biochemical and Pharmaceutical Aspects of Entrapment: the Possible Role of Free Radicals and Ozone in Nerve Root Compression. Riv It Ossigeno-Ozonot 2004;3(2):105-111.

9. Calunga-Fernandez JL, Ramos-Parra TL, Castillo P, Menendez-Cepedo S, Carballo A, Cespedes J. Ozonoterapia combinada en el tratamiento del paciente portador de hernia discal lumbar: estudio preliminar. Rev Cubana Invest Bioméd 2007;26(1). Available from: http://scielo.sld.cu/ scielo.php?script=sci_arttext\&pid=S0864-03002007000100003\&lng=es

10. Bonetti M. CT-Guided Oxygen-Ozone Infiltration into Isthmic Lysis Points in the Management of 1st Degree Spondylolisthesis and Spondylolysis. Riv It Ossigeno-Ozonot 2003;2(1):31-38.

11. Bonetti M, Cotticelli B, Richelmi P, Valdenassi L. Rofecoxib and O2-O3 Therapy vs O2-O3 Therapy in the Management of Spondylarthrosis. Riv It Ossigeno-Ozonot 2002;1(2):171-178.

12. Bonetti M, Fontana A, Mardighian D. Oxygen-ozone therapy for degenerative spine disease in the elderly. Riv It Ossigeno-Ozonot 


\section{6;5(1):25-32.}

13. Bonetti M, Fontana A, Parodi F. Oxygen-Ozone Therapy Associated with Magnetic Bioresonance in Degenerative Arthrosis of the Spine: Preliminary Findings. Int J Ozone Ther 2007;6(1):29-35.

14. Bonetti M, Fontana A, Martinelli F, Andreula C. Oxygen-ozone therapy for degenerative spine disease in the elderly: a prospective study. Acta Neurochir Suppl 2011;108:137-142.

15. Baeza-Noci J. Spinal Ozone Therapy in Lumbar Spinal Stenosis. Int J Ozone Ther 2007;6(1):17-24. 